\title{
PERGULATAN DOKTRIN DAN REALITAS DALAM PROSES TEORETISASI EKONOMI ISLAM
}

\author{
Hafas Furqani \\ Universitas Islam Negeri Ar-Raniry Banda Aceh, Indonesia \\ E-mail: hafasf@gmail.com
}

\begin{abstract}
This article examines the struggle between the doctrine and reality in the process of theorizing Islamic economics that until now remains a challenge in building the science of Islamic economics. The process of theorizing is a problem of epistemology and methodology. As a discipline in the realm of social sciences, Islamic economics uses authoritative sources of Islam (al-Qur'ân and Hadîth), logic and empirical experience. Islamic economic theory is expected to grow from all three of these sources. In contrast to conventional economic theory, the theory of Islamic economics is expected to grow from Islamic doctrine or principle of economy and rooted in empirical facts. The methodology of Islamic economics play a role in integrating doctrine and empirical reality in the process of theorizing Islamic economics. This article describes the three sources of Islamic economic epistemology, the link between doctrine and reality, and the interaction and integration of doctrine and reality in the process of theorizing Islamic economics. Islamic economic theory that is born must have integrity and be tested on three dimensions: doctrine, rationality, and empirical experience.
\end{abstract}

Keywords: Theorizing; Islamic economics; doctrine; reality.

\section{Pendahuluan}

Teoretisasi atau melahirkan teori masih menjadi tantangan yang harus dijawab dalam membangun ekonomi Islam sebagai sebuah disiplin ilmu. Proses teoretisasi ekonomi Islam mendapat perhatian ilmuwan yang terlibat dalam pembangunan keilmuan ekonomi Islam. Sebagai sebuah disiplin ilmu baru, tantangan ini masih belum dijawab dengan elegan yang menimbulkan pertanyaan kemampuan ekonomi Islam menjadi sebuah disiplin ilmu yang menawarkan sesuatu yang baru dalam kelompok ilmu-ilmu sosial. 
Setidaknya saat ini didapati dua pendekatan yang diambil oleh para ilmuwan, yaitu pendekatan Islamisasi teori ekonomi konvensional dan mencoba melahirkan teori ekonomi dari rahim epistemologi Islam itu sendiri. Pendekatan islamisasi teori ekonomi konvensional adalah pendekatan yang mainstream dalam diskursus ekonomi Islam. Dalam pendekatan ini, teori konvensional yang sudah ada dinilai kembali dari perspektif Islam. Kalau tidak ditemukan dimensi yang bertentangan dengan prinsip dasar Islam, teori tersebut dapat digunakan dalam kajian ekonomi Islam, namun jika sebaliknya, teori tersebut harus diubah (modifikasi) dengan perspektif Islam atau diganti dengan teori baru. Pendekatan ini telah dipakai sejak awal kemunculan ekonomi Islam. Pendekatan pragmatis ini, namun demikian, dikritik karena ekonomi Islam lebih banyak mereplikasi teori konvensional daripada menawarkan teori ekonomi baru.

Pendekatan kedua menghendaki sesuatu yang lebih genuine dalam proses teoretisasi ekonomi Islam di mana kita menggali kembali dari sumber-sumber ilmu yang diakui dalam tradisi epistemologi Islam, yaitu dari sumber wahyu, logika akal, dan fakta atau pengalaman nyata. Semua sumber ilmu tersebut diakui sebagai tempat berbagai konsep pengetahuan dan teori dapat dilahirkan dengan cara ilmiah tertentu untuk menentukan kebenaran ilmiah konsep ilmu atau teori yang dilahirkan tersebut. Pendekatan ini juga menghendaki adanya interaksi dan integrasi antara doktrin Islam dan realitas sosial ekonomi.

Pendekatan ini kelihatannya menarik karena akan menawarkan sesuatu yang baru. Namun demikian masih menjadi pertanyaan dalam konteks kajian metodologi ekonomi Islam adalah bagaimana kita bisa melahirkan konsep dan teori ekonomi Islam dari ketiga sumber ilmu tersebut? Bagaimana bentuk keterkaitan antara doktrin, logika dan realitas dalam proses teoretisasi ekonomi Islam? Bagaimana pula kita bisa memastikan kebenaran konsep dan teori yang dilahirkan?

\section{Sumber Ilmu Pengetahuan dan Doktrin Ekonomi Islam}

Dalam epistemologi Islam, setidaknya ada tiga sumber ilmu pengetahuan yang diakui, yaitu pengetahuan yang berasal dari wahyu Tuhan, ${ }^{1}$ logika nalar manusia ('aq $)^{2}$ dan dari pengamatan (observasi)

\footnotetext{
${ }^{1}$ Louay Safi mendefinisikan al-waby sebagai "pernyataan-pernyataan tertulis dalam bentuk diskursus yang mengandungi penjelasan tentang asal mula, hakikat, dan tujuan hidup manusia, dan juga alam, dan mengandungi kumpulan ajaran dan aturan hidup bagi manusia." Lihat Louay Safi, The Foundation of Knowledge: a Comparative
} 
pengalaman hidup manusia (anfus) atau fenomena alam (âfaq). Muhammad Hashim Kamali menglasifikasi sumber ilmu tersebut ke dalam dua bagian, yaitu ilmu transedental yang bersumber dari wahyu dan ilmu yang digali dari persepsi dan observasi yang bersumber dari pemikiran dan pengalaman manusia. ${ }^{3}$ Sejalan dengan klasifikasi tersebut, Naquib al-Attas membagi ilmu pengetahun kepada dua bagian, yang pertama ilmu pengetahun yang diberikan Tuhan kepada manusia melalui wahyu dan yang kedua adalah ilmu pengetahuan yang diperoleh melalui proses pemikiran rasional berdsarkan pengalaman dan spekulasi akal. Beliau mengatakan, ilmu yang pertama mengandung kebenaran objektif dan bersifat memberikan panduan (guidance) di mana ia menyingkap misteri kewujudan segara realitas dan menjelaskan hakikat hubungan manusia dengan dirinya, masyarakat dan Tuhannya. Pengetahuan ini menjadi dasar dan fondasi kepada pengetahuan yang kedua yang diperoleh melalui usaha rasionalisasi dalam memahami realitas. Pemisahan keduanya akan melahirkan kebingungan dan ketidakjelasan arah sehingga proses ilmiah menjadi usaha yang tidak ada tujuan yang pasti. ${ }^{4}$

Dalam bentuk klasifikasi yang lain, sumber ilmu diklasifikasi kepada dua macam yaitu, âyat (yang bersumber dari wahyu Tuhan, kalâm Allah dan fenomena alam, sunnat Allab) dan 'aql (yang berasal dari pemikiran manusia). Ayah (jamaknya âyat) tersebut kemudian diklasifikasi lagi kepada âyat qawliyah (berbentuk eksplisit yang merupakan kalam Allah dalam bentuk wahyu) dan âyat kawnŷah (yang berbentuk implisit dan dibaca dengan pengamatan dan perenungan yang mendalam dari alam semesta (âfâq) dan diri manusia sendiri

Study in Islamic and Western Methods of Inquiry (Kuala Lumpur: International Islamic University and International Institute of Islamic Thought, 1996), 174.

${ }^{2}$ Akal adalah prinsip-prinsip yang mengatur cara atau proses berpikir secara teratur. Akal adalah alat untuk mengetahui kebenaran. Ia juga kumpulan bangunan ilmu yang telah diuji dan dikumpulkan secara sistematis menggunakan prinsip-prinsip logika". Ibid., 175.

3 Muhammad Hashim Kamali, "Islam, Rationality and Science" Islam and Science, Vol. 1, No. 1 (2003), 115-134.

4 Syed Muhammad Naquib Al-Attas, "Preliminary Thoughts on the Nature of Knowledge and the Definition and Aims of Education", dalam Syed Muhammad Naquib Al-Attas (ed.), Aims and Objectives of Islamic Education (Jeddah: King Abdul Aziz University, 1979), 19-47. 
(anfus). ${ }^{5}$ Berdasar klasifikasi tersebut, sumber ilmu juga diklasifikasikan kepada al-Qur'ân al-takwîn (yaitu buku yang dicipta atau alam semesta) dan al-Qur'ân al-tadwîn̂̂ (buku yang ditulis atau al-Qur'ân itu sendiri). ${ }^{6}$

Klasifikasi sumber ilmu tersebut menunjukkan bahwa dalam Islam sumber ilmu pengetahuan tidak sempit, sehingga pengetahuan dapat digali berbagai sumber untuk kebutuhan manusia. Klasifikasi sumber ilmu pengetahuan tersebut juga menunjukkan bahwa sumber ilmu pengetahuan tersebut saling terkait dan seseorang tidak dapat memahami hakikat sesuatu hanya dengan merujuk kepada satu sumber ilmu saja. Penjelasan yang menyeluruh dan sempurna hanya akan didapat jikalau semua sumber ilmu tersebut dapat dibacara secara integratif dan komprehensif. Ziauddin Sardar dalam hal ini mengatakan:

The epistemology of Islam emphasizes the totality of experience and promotes not one but a number of diverse ways of studying nature. The Islamic concept of knowledge, 'ilm, incorporates almost every form of knowledge from pure observation to the highest metaphysics. Thus ilm can be acquired from revelation as well as reason, from observation as well as intuition, from tradition as well as theoretical speculation. ${ }^{7}$

S.H. Nasr pula menyatakan bahwa keseluruhan konsep Islam tentang pengetahuan didasarkan pada hierarki cara mengakses pengetahuan yang mulai dari wahyu sampai kepada berpikir logis (ratiocination) dan pada akhirnya pengetahuan empiris dan sensual dari pancaindra. Kesemuanya membentuk konsep yang padu terhadap pemahaman yang kita peroleh. ${ }^{8}$

Metodologi ekonomi Islam karena itu harus mengkaji bagaimana pengetahuan dan teori ekonomi Islam dapat dilahirkan dari berbagai sumber ilmu tersebut. Keberagaman sumber ilmu tersebut menjadi tantangan tersendiri kepada metodologi ekonomi Islam, karena

\footnotetext{
${ }^{5}$ Perkataan ayah atau ayat disebut di dalam al-Qur'ân sebanyak lebih dari 400 kali. Lihat Muhammad Hashim Kamali, "Reading the Signs: A Quranic Perspective on Thinking", Islam and Science, Vol. 4, No. 2 (2006), 141-165.

6 S. Waqar Ahmed Husaini, "Science, Technology and Environment in Islamic Culture: Basic Principles and Implications" dalam Klaus Gottstein (ed.), Islamic Cultural Identiy and Scientific-technological Development (Germany: Nomos Verlagsgesellschaft, 1986), 69-80.

7 Ziauddin Sardar, How Do You Know? Reading Ziauddin Sardar on Islam, Science, and Cultural Relations (London: Pluto Press, 2006), 133.

8 Seyyed Hossein Nasr, "The Islamic Worldview and Modern Science, MAAS Journal of Islamic Science, Vol. 10, No. 2 (1994), 33-50.
} 
berbagai interpretasi terhadap substansi pengetahuan dari pembacaan sumber ilmu secara langsung dan dari pengalaman atau kontekstualisasi pengetahuan sangat mungkin berbeda. Di samping itu, kriteria kebenaran tunggal mungkin tidak bisa didapat. Karena itu, perbedaan pendapat dalam membaca sumber ilmu dan memahaminya dalam kon teks realitas praktis adalah sesuatu yang mungkin terjadi.

Al-Qur'ân dan Hadîth sangat sentral dalam kerangka epistemologi Islam baik sebagai sumber ilmu atau referensi utama terhadap berbagai pengetahuan, maupun dalam mendefinisikan dan menentukan kriteria kebenaran sebuah pengetahuan. Al-Qur'ân dan Hadîth adalah sumber ilmu utama dalam Islam. Sebagai kalâm Allah, al-Qur'ân memiliki keistimewaan sebagai satu-satunya sumber ilmu yang dapat menyingkap realitas alam dan manusia secara komprehensif dan dapat menunjukkan kebenaran yang hakiki (baqq alyaqîn). Dengan kata lain, al-Qur'ân tidak sekadar berisi pesan-pesan normatif, tetapi juga menyingkap realitas dan perilaku manusia secara nyata.

Dalam konteks melahirkan teori ekonomi Islam, petunjuk dari Qur'ân dan Hadîth sebagaimana dikatakan oleh M. Raihan Sharif "menyediakan struktur dasar model ekonomi dan social masyarakat Islam. Pendirian dan pengoperasian institusi, perilaku, dan aksi sosial berangkat dari petunjuk-petunjuk tersebut". ${ }^{10}$

Dalam hal ini, ekonomi Islam sebagai ilmu yang berbasis dari ajaran agama tidak saja menggunakan petunjuk-petunjuk dari alQur'ân dan Hadîth dalam menjelaskan realitas dan tujuan kehidupan dunia, tetapi juga menjadikan tolok ukur keabsahan sebuah teori atau konsep ilmiah, di mana teori yang terlepas dari sandaran doktrin yang terdapat Qur'ân dan Hadîth tidak dianggap mewakili kebenaran yang sejati. Interaksi dan integrasi dengan prinsip dan doktrin dasar ajaran agama menjadi sebuah keniscayaan dalam tradisi epistemologi Islam untuk meraih haqq al-yaqîn.

Namun demikian, patut dicatat juga bahwa dalam bidang sosial ekonomi, al-Qur'ân hanya menyediakan prinsip-prinsip dasar dan

9 Allah menyebut al-Qur'ân sebagai pernyataan yang benar (wa man așdaq min Allah qîlâ) (Q.S. al-Nisâ' [4]: 122), pernyataan yang berat (qawl thaqî̉) (Q.S. al-Muzammil [73]: 5), yang tidak ada keraguan (lâ rayb fî̀) (Q.S. al-Baqarah [2]: 2) dan petunjuk kepada kebenaran dan keadilan (yahdî li al-latî hiya aqwam) (Q.S. al-Isrâ' [17]: 9).

10 M. Raihan Sharif, Guidelines to Islamic Economics: Nature, Concepts, and Principles (Bangladesh: Bangladesh Institute of Islamic Thought, 1996), 63. 
ajaran ekonomi secara garis besar saja. Rata-rata prinsip-prinsip dasar tersebut tidak begitu eksplisit untuk bisa diterapkan secara langsung dalam konteks kehidupan ekonomi manusia. Prinsip-prinsip umum tersebut menjadi panduan dalam menghasilkan kerangka pengetahuan dan teori ekonomi Islam. Dalam hal ini, interpretasi terhadap prinsipprinsip umum dan ajaran-ajaran tersebut diperlukan untuk mendapat ilustrasu jelas mengenai pandangan al-Qur'ân terhadap fenomena ekonomi sehingga proses konseptualisasi dan teoretisasi berlangsung sempurna yang pada akhirnya bisa diaplikasi dalam kehidupan ekonomi.

Proses interpretasi ini menjadi salah satu isu sentral dalam metodologi ekonomi Islam. Ini karena berinteraksi dengan doktrin dan prinsip Islam tentang ekonomi sebagaimana yang digambarkan dalam al-Qur'ân—menurut Naqvi dan Safi-harus dilakukan terlebih dahulu sebelum teori ekonomi Islam dilahirkan. ${ }^{11}$ Dengan kata lain, aksioma, prinsip, doktrin dan visi Islam tentang ekonomi harus digali terlebih dahulu sebagai landasan filsafat dan kerangka konseptual yang berfungsi sebagai fondasi, parameter, petunjuk dan rujukan dalam melahirkan berbagai postulat, asumsi, hipotesis, dan teori ekonomi Islam. Dalam perspektif ini, konsep dan teori ekonomi Islam tidak lahir secara liar dari semata-mata spekulasi akal atau pengalaman empiris terlepas dari fondasi filsafat dan doktrin dasar yang jelas dalam al-Qur'ân dan Hadîth.

Menurut Haneef ini dapat dilakukan dengan mengumpulkan ayatayat dan Hadîth Nabi yang berkaitan dengan ekonomi, seperti konsep dan perilaku manusia dalam aktivitas ekonomi berkaitan dengan harta, sesama manusia, dan alam dalam aspek produksi, konsumsi, distribusi, keuangan, pemerintahan, pasar dan lain sebagainya yang menggambarkan ajaran-ajaran Islam dalam aspek ekonomi. ${ }^{12}$

Petunjuk wahyu tentang ekonomi bisa dikategorikan ke dalam dua bentuk, yaitu petunjuk yang berkaitan ajaran normatif ekonomi Islam dan petunjuk ynag menjelaskan aspke positif perilaku manuasia dalam dimensi ekonomi.

Dalam dimensi normatif, al-Qur'ân dan Hadîth memberi petunjuk bagaimana seharusnya manusia berperilaku dan bagaimana seharusnya

11 Lihat S. N. H. Naqvi, Ethics and Economics: An Islamic Synthesis (United Kingdom: The Islamic Foundation, 1981).

12 Mohamed Aslam Haneef, "Islam: the Islamic Worldview and Islamic Economics", IIUM Journal of Economics and Management, Vol. 5, No. 1 (1997), 39-65. 
kondisi sosial ekonomi masyarakat yang diinginkan. Dalam dimensi positif, al-Qur'ân dan Hadîth menjelaskan bagaimana tendensi perilaku manusia terhadap harta, terhadap lingkungan dan sesama masyarakat. Seringkali kita dapati al-Qur'ân dan Hadîth memilah perilaku ekonomi manusia berdasarkan komitmen kepada dimensi normatif (moral) yang juga diterangkan dalam al-Qur'ân. Dalam hal ini, wahyu tidak menyamakan semua perilaku dalam satu bentuk tetapi membeda-bedakannya sesuai dengan kepatuhan kepada aspek moral yang diinginkan. Petunjuk-petunjuk tersebut harus digali oleh ilmuwan ekonomi Islam untuk selanjutnya dijadikan dasar pembuatan teori ekononi Islam.

Naqvi mengajukan axiomatic approach (pendekatan aksiomatik) dengan mengembangkan beberapa aksioma etika (axiomatic values) dan sistem nilai (value system) yang digali secara langsung dari al-Qur'ân dan Hadîth. Prinsip etika tersebut menggambarkan secara umum dan keseluruhan ajaran Islam tentang ekonomi. ${ }^{13}$ Pendekatan ini menurut Naqvi ada beberapa keunggulan karena ekonomi Islam mengehendaki nilai dan etika Islam mendominasi segala aktivitas dan sistem perekonomian. Aksioma etika tersebut akan berfungsi sebagai (1) sumber dan dasar postulat yang diperlukan untuk membuat sebuah generalisasi pernyataan ekonomi, (2) sumber untuk melahirkan hipotesis yang tidak terbantahkan berkaitan dengan perilaku ekonomi, dan (3) dasar untuk melakukan evaluasi, penyesuaian dan peningkatan lebih lanjut praktik ekonomi Islam dalam masyarakat. ${ }^{14}$

Muhammad Akram Khan menyetujui pendekatan tersebut di mana beberapa ayat al-Qur'ân dan Hadîth yang membincangkan fenomena ekonomi dikumpulkan untuk membangun kerangka konsep ekonomi Islam. Konsep tersebut menjadi rujukan yang tidak perlu diverifikasi atau dikonfirmasi dalam dunia nyata. Sebaliknya, teori ekonomi Islam harus diuji berdasarkan prinsip Islam tersebut. Jika memang terbukti perbedaan di antara keduanya, maka teori bisa ditolak untuk pengujian berikutnya. ${ }^{15}$

Biraima berusaha mengaplikasikan pendekatan tersebut dengan membangun model Qur'ani dalam pola konsumsi. Secara umum,

13 Lihat S. N. H. Naqvi, Islam: Economics and Society (London: Kegan Paul International, 1994), 153.

14 Ibid., 155.

${ }^{15}$ Muhammad Akram Khan, "Methodology of Islamic Economics", Journal of Islamic Economics, Vol. 1, No. 1 (1987), 17-33. 
menurutnya, al-Qur'ân membicarakan dua bentuk konsumsi, yaitu: (1) konsumsi yang dianjurkan oleh Allah untuk kebaikan dan kesenangan manusia, dan (2) konsumsi yang disuruh oleh iblis untuk semata-mata kesenangan manusia. Kedua pola konsumsi ini dapat dilihat dalam kehidupan sehari-hari manusia. Dalam pola pertama (sebagaimana dianjurkan Allah), seorang individu berusaha untuk mengarahkan perilaku konsumsinya untuk hal-hal yang baik, bebas dari mengonsumsi sesuatu yang dilarang, mengingat Tuhan dan bersyukur atas konsumsi yang dilakukan. Dalam pola kedua (sebagaimana dianjurkan oleh iblis), seorang individu melakukan konsumsi terhadap sesuatu yang dilarang agama, semata-mata untuk kepuasan diri dan lupa bersyukur dan mengingat Tuhan dalam konsumsi yang dilakukan. Kerangka normatif ini berhubung secara positif dengan realitas perilaku konsumsi manusia, dan demikian pula sebaliknya. ${ }^{16}$

M. Raihan Sharif mengingatkan bahwa usaha ini sebenarnya adalah untuk membangun kerangka filsafat moral Islam dalam bidang ekonomi yang selanjutnya menjadi referensi pengembangan teori ekonomi Islam untuk menjelaskan berbagai model realitas ekonomi dan perilaku manusia dalam kehidupan ekonomi mereka. Perbedaan interpretasi dalam membangun konsep dan melahirkan teori ekonomi Islam sangat mungkin terjadi melihat kedinamikaan realitas dan cara berpikir manusia. Interpretasi-interpretasi baru sangat dimungkinkan. ${ }^{17}$

\section{Realitas dan Doktrin Ekonomi Islam}

Fakta, pengalaman, dan realitas praktis—sebagaimana yang dialami manusia dan menjadi bagian sejarah kehidupan manusiaadalah juga sumber ilmu yang diakui dalam epistemologi Islam. AlQur'ân memberitahukan bahwa manusia dapat mengobservasi alam, lingkungan dan pengalaman hidupnya menggunakan pancaindra untuk mendapatkan pengetahuan. ${ }^{18}$

Pendekatan yang digunakan biasanya bersifat induktif dengan mengumpulkan fakta atau serial data (data series). Dari observasi yang

\footnotetext{
16 Mohammad E. Biraima, "A Quranic Model for a Universal Economic Theory”, JKAU: Islamic Economics, Vol. 3 (1991), 3-42.

17 Sharif, Guidelines to Islamic Economics, 49.

18 Namun demikian, epistemologi Islam mengakui bahwa kebenaran tidak sepenuhnya bisa dicapai berdasarkan akal atau persepsi pengalaman semata-mata karena akal dan fakta atau pengalaman tidak selalu menggambarkan kebenaran secara komprehensif karena banyak perkara lain yang tidak bisa dicapai menurut akal atau dengan pancaindra padahal perkara tersebut juga merupakan kebenaran.
} 
dilakukan, berdasarkan pengamatan sejumlah pengalaman dan data statistika, hipotesis diajukan untuk diuji kebenarannya dan teori dibangun untuk menjelaskan fenomena realitas yang berlaku. Pengajuan hipotesis dan pengembangan teori adalah bagian dari penalaran logis dari data atau pengalaman yang ada dengan tujuan menjelaskan fenomena ekonomi yang kompleks dan juga tendensi perilaku manusia.

Muhammad Hashim Kamali menjustifikasi pendekatan tersebut dan mengatakan bahwa penalaran induksi adalah pendekatan yang dianjurkan dalam al-Qur'ân. Dalam banyak tempat al-Qur'ân menyuruh kita berpikir, berkontemplasi, melihat dan mengamati alam semesta dan juga pengalaman hidup manusia. ${ }^{19}$ Menurutnya, al-Qur'ân yang memulai semangat penalaran induktif dan karena itu menjadi kewajiban agama untuk setiap Muslim mempelajari, memahami dan mengembangkan metode tersebut untuk menyingkap pengetahuan dari fenomena alam dan masyarakat.

Dengan sumber ilmu yang beragam dan metodologi yang coba menyeimbangkan dan mengintegrasikan berbagai sumber ilmu tersebut, menimbulkan pertanyaan di mana posisi ekonomi Islam sebagai sebuah ilmu dalam memandang 'doktrin' yang bersumber dari agama sebagai prinsip yang tidak berubah dan 'realitas' fenomena ekonomi yang dinamis. Kemudian, bagaimana metodologi ekonomi Islam dapat menghubungkan dan mengintegrasikan doktrin dan realitas ekonomi dalam sebuah teori ekonomi? ataupun secara lebih fundamental, apakah ekonomi Islam itu sebuah ilmu atau sebuah doktrin/sistem?

Volker Nienhaus dan M. Baqir al-Sadr mencoba menjawab pertanyaan tersebut. Menurut Nienhaus, ekonomi Islam sebagai sebuah ekonomi yang berdasarkan agama banyak dianggap sebagai doktrin rigid, stagnan, dan tidak menerima sembarang perubahan, daripada sebagai sebuah ilmu yang lebih dinamis dan bisa menerima perubahan. Sejatinya ekonomi Islam-menurut Nienhaus-harus dianggap sebagai sebuah ilmu, bukan doktrin yang dikembangkan dengan investigasi ilmiah menggunakan berbagai metode ilmiah yang dikenal dalam ilmu ekonomi. ${ }^{20}$

\footnotetext{
${ }^{19}$ Kamali, Islam, Rationality, and Science, 121.

${ }^{20}$ Volker Nienhaus, "Islamic Economics: Dogma or Science" dalam Kay Hafez (ed.), The Islamic World and the West (Leiden: EJ Brill, 2000), 86-99.
} 
Ekonomi Islam sebagai ilmu menerima masukan dan perubahan yang dinamis akibat penelitian ilmiah yang tidak bisa dilakukan jika ekonomi Islam dianggap sebagai sebuah doktrin yang kaku. Sebagai sebuah ilmu, ekonomi Islam harus mengembangkan berbagai metode untuk mengantisipasi berbagai perbedaan pemikiran dan cara pandang akibat penilaian ilmiah yang dilakukan. Ekonomi Islam haruslah menjadi sebuah disiplin ilmu terbuka di mana segala perbedaan dapat diselesaikan sendiri melalui pendekatan argumentasi persuasif daripada pemaksaan doktrin-doktrin kaku dan keras dalam kehidupan manusia. Lebih lanjut, tujuan ilmu adalah memajukan pengetahuan kita terhadap sesuatu dan menurut Nienhaus, "hanya ekonomi positif yang dapat memajukan pengetahuan kita berkaitan dunia ekonomi yang nyata untuk memberikan pemahaman yang menyeluruh dan penilaian berbagai masalah dalam kerangka nilai dan norma ekonomi". ${ }^{21}$

Al-Sadr sebaliknya mengatakan bahwa ekonomi Islam pada hakikatnya adalah sebuah doktrin (mazhab) ${ }^{22}$ dan bukan sebuah ilmu. Ekonomi Islam adalah sebuah doktrin dengan prinsip-prinsipnya digali dari sumber yang diterima Islam sebagai asas pengetahuan yaitu al-Qur'ân dan Hadîth. Menurut al-Sadr, ekonomi Islam adalah sebuah doktrin yang berusaha untuk "menemukan aturan dan prinsip Islam dalam kehidupan ekonomi menuju terwujudnya keadilan sosial". ${ }^{23}$ Ekonomi Islam bukan sebuah disiplin ilmu yang bertujuan untuk

21 Volker Nienhaus, "Restaments of Normative Economics: Western Approach and Islamic Perspectives" dalam Masudul Alam Choudhury (ed.), Policy-Theoretic Foundations of Ethico-Economics (Cape Bretton: The Centre of Humanomics, University College of Cape Bretton, 1988), 58.

22 Perkataan mazhab yang digunakan oleh Baqir al-Sadr diterjemah ke dalam bahasa Inggris dan Bahasa Indonesia dengan berbagai makna seperti sistem, aliran pemikiran (school of thought), dan doktrin. Kalau kita membacara teks asli Iqtisâadunâ dalam bahasa Arab, kadangkala maz̧hab lebih sesuai diartikan sistem karena al-Sadr mencoba membandingkan antara sistem ekonomi Islam dan kapitalisme atau sosialisme. Namun demikian, kadangkala, ia lebih sesuai diartikan sebagai 'aliran pemikiran' karena al-Sadr mencoba membuktikan bahwa ekonomi Islam adalah aliran pemikiran ekonomi yang ketiga. Kadangkala ia lebih sesuai juga diartikan sebagai doktrin karena pendekatan al-Sadr dalam membangun ekonomi Islam adalah dengan menderivasi prinsip-prinsip Islam dalam bidang ekonomi dari alQur'ân dan Ḥadîth untuk menjadi basis dan rujukan ekonomi Islam. Penulis mengambil makna yang terakhir untuk mendiskusikan masalah ini. Lihat Muhammad Baqir Al-Sadr, Iqtisaduna: Our Economics (Tehran, Iran: World Organization for Islamic Services, 1983).

23 Ibid., Vol. 2, 10. 
"menginterpretasikan realitas dalam menjelaskan kehidupan ekonomi, berbagai peristiwa dan fenomena ekonomi dengan uraian sebab akibat atau faktor yang melatari peristiwa tersebut". ${ }^{24}$ Sebaliknya, ekonomi Islam adalah sebuah doktrin yang menurut al-Sadr memainkan peranan "untuk menyingkap visi keseluruhan Islam dalam bidang ekonomi berdasarkan sharî‘ ah dan mempelajari konsep atau ide yang muncul dari visi Islam tersebut". 25

Perdebatan ini menunjukkan bahwa ada perbedaan pendapat di kalangan ilmuan berkaitan dengan hakikat ekonomi Islam. Satu pihak menghendaki 'keilmiahan' ekonomi Islam sebagai sebuah disiplin ilmu, sementara pihak yang lain menginginkan ekonomi Islam lebih berperan sebagai sebuah doktrin yang membimbing ke arah pencapaian tujuan hidup ketimbang sebagai disiplin ilmu yang hanya menjelaskan realitas ekonomi tentang apa dan bagaimana sebuah fenomena terjadi dan kering dari idealisme yang mengantar manusia ke arah yang sepatutnya.

Namun demikian, menurut pandangan kami, ekonomi Islam mestilah dipandang sebagai sebuah ilmu dan sebuah doktrin/sistem secara bersamaan. Ekonomi Islam adalah kombinasi doktrin yang menjadi landasan filsafat dan kerangka konseptual terhadap realitas ekonomi. Realitas ekonomi dalam hal ini tidak terjadi begitu saja, tetapi adalah manifestasi doktrin yang dianut oleh manusia sebagai makhluk ekonomi. Karena itu, kita mendapati realitas ekonomi dalam sebuah masyarakat yang mempunyai pegangan agama mungkin berbeda dengan perilaku ekonomi masyarakat yang nilai-nilai hidupnya dipandu oleh filsafat sekularisme dna materialisme.

Sebagai sebuah ilmu, ekonomi Islam coba melakukan interaksi dan integrasi antara doktrin Islam dan realitas ekonomi. Metodologi ekonomi Islam akan melahirkan cara-cara interaksi dan integrasi doktrin dan realitas dan melahirkan kerangka pengetahuan atau teori yang dapat menangkap dan menghubungkan doktrin dan realitas prkatis, idealisme dan pengalaman nyata, dimensi ekonomi normatif dan positif.

Karena itu, perdebatan seharusnya bukan pada apakah ekonomi Islam sebuah ilmu atau doktrin. Ini karena doktrin bukan saja relevan terhadap ilmu ekonomi Islam, tetapi lebih dari itu, tidak ada sebuah ilmu yang netral dari doktrin atau worldview yang membimbing dan

\footnotetext{
${ }^{24}$ Ibid., Vol. 2, 6.

${ }^{25}$ Ibid., Vol. 2, 37.
} 
melandasi filsafatnya. ${ }^{26}$ Pertanyaannya seharusnya adalah bagaimana hubungan antara doktrin dan realitas dalam ilmu ekonomi Islam ataupun lebih teknis lagi, bagaimana kita dapat menghubungkan doktrin Islam dan realitas ekonomi

Ilmu ekonomi modern didahului oleh apa yang disebut oleh Schumpeter dan Heilbroner sebagai sebuah visi atau ideologi dalam mengonsepsikan filsafat dan subtansi ilmu ekonomi. ${ }^{27}$ Visi atau ideologi tersebut berbentuk prakonsepsi yang merefleksikan kepercayaan yang dipegang oleh komunitas ilmiah, atau dalam istilah Sardar adalah sebuah absolute frame of reference yang menyediakan bahan baku terhadap proses analisis ilmiah oleh ekonom. Rata-rata visi atau idelogi tersebut dibentuk oleh filsuf atau pemikir ekonomi dalam memandang realitas ekonomi. ${ }^{28}$ Visi atau doktrin tersebut adalah bagian inti (bard-core) yang tidak boleh dinegasi atau dimodifikasi dan terjaga dari proses falsifikasi. ${ }^{29}$ Ini karena doktrin tersebut menurut Mannan menyediakan "prinsip-prinsip yang mengatur sistem kehidupan secara keseluruhan, tidak mengenal batas waktu, dan berfungsi sebagai mekanisme otomatis yang merangsang pemikiran

\footnotetext{
${ }^{26} \mathrm{Ilmu}$ Ekonomi menurut Gailbraith telah digunakan bukan saja sebagai ilmu tetapi juga untuk mendukung ideologi atau kepercayaan tertentu. Beliau mengatakan "sebuah model ekonomi yang diterima tidak semestinya karena ia bisa menerangkan realitas, tetapi karena ia mampu mengalihkan perhatian dari pertanyaan-pertanyaan yang memiliki urgensi sosial yang berimplikasi pada sebuah aksi politik. Dengan kata lain, ilmu ekonomi bukanlah sebuah ilmu tetapi sebuah sistem kepercayaan yang mengatakan bahwa sebuah ideologi/doktrin tersebut sebagai sebuah ilmu". Lihat John Kenneth Galbraith, "Economics as A System of Belief", dalam Andrea D. Williams (ed.), A Contemporary Guide to Economics, Peace, and Laughter (USA: Houghton Muffin Company, 1971), 64.

27 Heilbroner melihat ideologi sebagai konstruksi realitas sosial dan kerangka bagaimana masyarakat berpikir, merasakan dan menafsirkan berbagai hubungan atau realitas dalam kehidupan mereka". Karena itu, ideologi adalah bagian dari ilmu ekonomi karena "ia menjadi motivasi yang bukan saja kuat dan tidak dapat dihindari, tetapi juga legitimate." Robert Heilbroner, "Economics As Ideology", dalam Warren J. Samuels (ed.), Economics As Discourse: An Analysis of the Language of Economics (USA: Kluwer Academic Publishers, 1990), 105.

${ }^{28}$ Wisman dalam hal ini mendefinisikan doktrin sebagai "asumsi-asumsi yang sangat kompleks berkenaan realitas sosial yang diterima begitu saja (uncritically) oleh ilmu ekonomi, jika tidak diterima secara tidak sadar (unconsciously), dan berdasarkan doktrin tersebut ilmu ekonomi dibentuk". Lihat Jon D. Wisman, "Economic Science's Bondage to the Material Progress Vision", Humanomics, Vol. 8 No. 2 (1992), 5.

${ }^{29}$ M. Umer Chapra, The Future of Economics: An Islamic Perspective (UK: The Islamic Foundation, 2000), 140.
} 
baru terhadap berbagai masalah dan isu yang ditemukan dalam dunia nyata. ${ }^{30}$

Ekonomi sebagai sebuah ilmu dan sistem sebenarnya adalah manifestasi sistematis doktrin atau filsafat yang dipegang dalam alam realitas. Hakikatnya, ekonomi kapitalisme — sebagaimana disebut oleh Spengler — adalah produk pengalaman atau realitas masyarakat Barat yang kalau kita tarik kembali garisnya akan sampai kepada zaman Romawi dan Yunani kuno. Ekonomi Kapitalisme karena itu sangat identik dengan kepercayaan tertentu yang berkembang dalam masayarakat Barat dan terakumulasi dalam pengalaman yang berterusan semenjak zaman pencerahan (enlightenment), kebangkitan (renaissance), revolusi industri, hingga zaman modern ini. ${ }^{31}$

Asumsi perilaku manusia dalam membuat pilihan atau memecahkan masalah ekonomi, misalnya, diambil dari cara pandang dan falsafah Barat dalam melihat hakikat manusia. Manusia dianggap sebagai pusat alam realitas yang mempunyai daya gravitasi menarik segala sesuatu menuju ke arahnya. Dalam pandangan ini, self-interest dianggap sebagai perilaku utama manusia dalam melakukan aktivitas ekonominya, baik dalam konsumsi, produksi atau distribusi. Kaca pandang tersebut melekat kepada manusia ekonomi (bomoeconomicus) di mana seseorang-sebagai konsumen atau produsen-akan berusaha memaksimalisir kepentingan dan kepuasan diri dalam bentuk materi terlepas dari kekangan agama atau aturan normatif.

Asumsi tersebut ditentang oleh kebanyakan para ilmuwan karena dianggap tidak merepresentasikan perilaku manusia yang seutuhnya. Asumsi tersebut digali dari pemahaman yang bersifat materialis (yang menganjurkan kepuasan materil), reduksionis (yang mereduksi hakikat manusia kepada satu dimensi self-interest dan melupakan bahwa manusia juga makhluk sosial) dan sekularis (yang memisahkan nilainilai spiritual dalam perilaku ekonomi). Doktrin tersebut dibangun seiring dengan perkembangan masyarakat Barat dan etos yang dilaluinya yang tidak semestinya merefleksikan fakta yang sebenarnya.

\footnotetext{
30 M. A. Mannan, Islamic Economics: Theory and Practice (Cambridge: Hodder and Stoughton, 1986), 14-15.

31 Spengler misalnya mengatakan the content of economic thought was not initially independent of the socio-physical parameters of the society within which it developed, nor did it ever become completely independent even in modern times. Lihat Joseph J. Spengler, Origins of Economic Thought and Justice: Political and Social Economy (Carbondale: Southern Illinois University Press, Carbondale, 1980), xiii.
} 
Menyadari hal tersebut, para ilmuwan saat ini menawarkan hakikat manusia ekonomi dengan asumsi yang lebih komprehensif dengan memasukkan nilai-nilai spiritual, dimensi sosial dan transedental untuk menjelaskan perilaku manusia.

Karena itu, argumentasi yang mengatakan bahwa ekonomi adalah ilmu yang murni menjelaskan fakta dan bebas dari nilai ataupun doktrin tertentu tidak benar sama sekali. Demikian juga argumentasi yang mengatakan bahwa proses ilmiah telah memastikan bahwa unsur-unsur normatif hilang dalam teori ekonomi juga tidak benar. Sebaliknya, yang ada adalah ilmu ekonomi telah mengalami proses penyaringan dari berbagai nilai kepada nilai tertentu yang diyakini oleh para filsuf ekonomi dan merefleksikan sebuah masyarakat. Ilmuwan ekonomi Islam menyadari betul akan hal tersebut dan ini menyebabkan mereka menyusun ilmu dan sistem ekonomi yang berlandaskan doktrin atau filsafat Islam.

\section{Menginteraksikan Doktrin dan Realitas}

Doktrin ekonomi Islam didefinisikan oleh Fazlur Rahman sebagai "prinsip-prinsip ekonomi dalam Islam yang menyediakan orientasi umum dan jelas terhadap tujuan ekonomi dan kerangka besar program ekonomi dalam Islam", ${ }^{32}$ Doktrin ekonomi Islam menurut Abdul-Rauf adalah "kerangka sistem nilai Islam yang berkaitan dengan kehidupan ekonomi manusia". ${ }^{33}$ Doktrin ekonomi Islam sebenarnya adalah idealisasi realitas berdasarkan perspektif Islam dan juga prinsip-prinsip dan nilai-nilai Islam yang dapat mengantarkan seseorang menuju idealisme tersebut. ${ }^{34}$

Menurut Abdul-Rauf doktrin ekonomi Islam adalah bagian dari konsep Islam tentang kehidupan (islamic concept of life). Doktrin ekonomi Islam ini ada dalam tiga bentuk, yaitu: pertama, nilai-nilai dasar dan batasan-batasan yang ditetapkan Allah (budud Allah) yang dibolehkan dan yang dilarang; kedua, panduan umum (general guidelines) yang membimbing kebebasan manusia dalam melakukan aktivitas ekonomi; dan ketiga, aturan-aturan yang mengatur perilaku manusia

\footnotetext{
32 Fazlur Rahman, "Islam and the Problem of Economic Justice" Journal of Islamic Economics, Vol. 3, No. 2 (1995), 13-51.

${ }_{33}$ Muhammad Abdul-Rauf, Ummah and the Muslim Nation (Kuala Lumpur: Dewan Bahasa dan Pustaka, 1991), 92.

${ }^{34}$ Naqvi, Islam: Economics and Society, xx.
} 
sebagai individu dan masyarakat sehingga tercipta keteraturan dalam kehidupan ekonomi. ${ }^{35}$

Doktrin ekonomi Islam dikembangkan dari cara pandang Islam yang dibentuk dan diberitahukan dalam al-Qur'ân dan Hadîth. Doktrin ekonomi Islam dibangun dari berbagai konsep dalam alQur'ân dan Hadîth mengenai Tuhan, manusia dan alam, dan hubungan berbagai realitas tersebut. Doktrin tersebut bersifat komprehensif dan seimbang menerangkan seluruh dimensi kehidupan manusia. ${ }^{36}$

Dalam hal ini Baqir al-Sadr menerangkan Islamic doctrine and teachings are not confined to organizing the outward form of society, but go deep into its spiritual and ideological depths so that internal content will be in consonance with economic and social plan of Islam [Doktrin dan ajaran Islam tidak selalu mengelola 'struktur luar masyarakat', tetapi masuk lebih dalam ke dimensi spiritual dan ideologi, sehingga substansi doktrin tersebut terlihat dalam aktivitas dan perencanaan ekonomi dan sosiall. ${ }^{37}$

Doktrin menyediakan prinsip-prinsip dasar sebagai fondasi ekonomi Islam dalam menentukan tujuan dan orientasi ilmiah dan juga dalam membangun asumsi dan hipotesis untuk melahirkan teori ekonomi Islam. ${ }^{38}$ Sebagai sebuah ilmu, ekonomi Islam akan menformulasikan teori perilaku ekonomi berdasarkan aturan dan etos al-Qur'ân. ${ }^{39}$ Naqvi juga mengatakan Islamic economics is about enunciating

\footnotetext{
35 Abdul-Rauf, Ummah and the Muslim Nation, 89.

36 Al-Qur'ân sebagai sumber doktrin ekonomi Islam, dijamin oleh Allah membawa kepastian dan bebas dari kecacatan, distorsi dan kontradiksi (12:2; 13:37; 41:44). Dalam epistemologi Islam, ilmu membawa keyakinan dan kepastian (yaqîn) tanpa ada keraguan atau kesalahan. Ilmu membawa makna haqq (kebenaran dan kepastian), lawan kepada jabl (ketidaktahuan) atau zann (ketidakpastian). Al-Qur'ân (12:76; 29:43; 58:11) mendorong manusia untuk memiliki ilmu ('ilm), karena ilmu dapat mengantar kepada haqq. Sebaliknya, jabl atau mengikuti zann adalah sikap menjauhi ḥaqq (6:25; 7:199; 53:28).

37 Muhammad Baqir Al-Sadr, "General Edifice of the Islamic Economy" dalam Jomo K.S (ed.), Islamic Economics: Contemporary Ulama Perspectives (Kuala Lumpur: Iqra', 1991), 31-48.

${ }^{38}$ Hasan Askari, "Islamic Definition of the Economics" dalam Society and State in Islam: An Introduction (Lahore, Pakistan: Progressive Books, 1979), 142.

39 Siddiqi mengatakan berdasarkan doktrin tersebut, ekonomi Islam akan berusaha to formulate the theory of economic behavior according to the injunctions and ethos of the Qur'an. Muhammad Nejatullah Siddiqi, The Economic Enterprise in Islam (Lahore, Pakistan: Islamic Publications, Cet Ke-2, 1979).
} 
a significant number of falsifiable statements about economic behavior of 'representative' Muslims in a typical real-life Muslim society with reference to the ideals that impart it a distinct personality. ${ }^{40}$

Di sisi lain, peran fakta dan realitas sejarah pengalaman manusia juga penting dalam formulasi teori ekonomi Islam. Meremehkan realitas atau fakta yang berlaku dalam masyarakat ketika menformulasikan teori ekonomi Islam akan menyebabkan teoretisasi ekonomi Islam sebagai usaha yang sia-sia karena tidak mengakar dalam kenyataan. Hal ini penting, karena bagi Naqvi: Muslim economists should not create the impression that they are enunciating some synthetic, universal truth, without subjecting their theories to the toughest tests, and to discard old theories once enough contrary to evidence, a priori and/or empirical, becomes available. [Ekonom Muslim jangan menciptakan impresi bahwa mereka mengajukan teori yang mengandung kebenaran universal, tanpa diuji dengan tes yang berat, teori lama bisa diabaikan jika bertentangan dengan fakta atau bukti empiris yang wujud]. ${ }^{41}$

Ziauddin Sardar juga berargumentasi bahwa ekonomi Islam sebagai ilmu yang dibangun di atas tradisi Islam, baru mempunyai arti jikalau beroperasi dalam konteks masyarakat Islami atau peradaban Islami. Ekonomi Islam dalam hal ini tidak bisa hanya mengandalkan prinsip dan ajaran Islam, tetapi mesti membangun instrumen analisa dan institusi ekonomi yang tersendiri sebagai tempat doktrin, prinsip dan ajaran Islam dimanifestasikan. ${ }^{42}$

Dalam hal ini, teori ekonomi Islam harus diuji dengan realitas praksis, kondisi nyata perilaku individu dan masyarakat. Teori ekonomi Islam harus siap menghadapi kejutan eksternal (exogeneous shocks) dalam konteks perubahan sosial untuk memenuhi kriteria ilmiah dalam sebuah teori. Lebih lanjut, menurut Naqvi teoretisasi ekonomi Islam adalah tentang pengajuan pernyataan-pernyataan yang bisa difalsifikasi terhadap perilaku Muslim dalam konteks kehidupan tipikal masyarakat Muslim dengan merujuk kepada idealisme atau doktrin Islam yang mempengaruhi perilaku atau kondisi riil masyarakat. ${ }^{43}$

Namun demikian, pendekatan yang diambil mungkin agak berbeda dengan ekonomi konvensional. Dalam ekonomi Islam, sisi

${ }^{40}$ Naqvi, Islam: Economics and Society, xix.

${ }^{41}$ Ibid., xx.

42 Ziauddin Sardar, Islamic Futures: The Shape of Ideas to Come (Islamic Futures and Policy Studies) (New York: Mansell, 1986), 209.

${ }^{43}$ Ibid., xix. 
praktis realitas ekonomi didekati dengan pendekatan komprehensif dengan tidak memisahkan sisi 'apa yang terjadi' (what is?) sebagaimana dirasa, dialami, atau diamati oleh manusia (disebut juga sebagai dimensi wâqi îyah), dengan sisi 'apa yang seharusnya terjadi' (what should be?) yang merupakan dimensi normatif atau doktrin ekonomi Islam (disebut juga sebagai haqq).

Ekonomi Islam berusaha menghubungkan atau menyatukan kedua dimensi tersebut. Penyatuan dimensi realitas dan doktrin, fakta dan idealisme, wâqi îyah and ḥaqq, adalah tujuan epistemologi Islam. Ekonomi Islam sebagai sebuah ilmu berusaha menghubungkan dan menyatukan doktrin dan realitas dalam asumsi, hipothesis dan teori yang dikembangkan. Fakta atau realitas ekonomi (wâqi îyah) yang menyatu dengan doktrin ekonomi Islam kita sebut sebagai haqîqah (hakikat yang menggambarkan keduanya, fakta dan doktrin). Haqîqah dalam hal ini berarti dimensi praktis ekonomi yang mengambarkan keduanya, realitas (wâqi îyah) dan kebenaran (haqq). Dengan kata lain, keduanya, doktrin dan realitas, menunjukkan satu objek kebenaran yang sama. ${ }^{44}$

Realitas-praksis dalam hal ini dipahami sebagai manifestasi eksternal sesuatu yang diyakini atau dipercayai oleh seseorang dalam bentuk perilaku perbuatan. Seorang Muslim-dengan kepercayaan akan ajaran-ajaran Islam-akan memanifestasikan doktrin atau ajaran tersebut dalam kehidupan nyata.

\section{Arah Baru Metodologi Ekonomi Islam}

Menghubungkan doktrin dan realitas menjadi tantangan metodologi ekonomi Islam. Doktrin lebih bersifat normatif mengandung ajaran dan prinsip ekonomi Islam yang disampaikan

\footnotetext{
44 Muhammad Fazlur-Rahman Ansari menambahkan bahwa ḅaqîaah sebenarnya adalah manifestasi keimanan dalam kenyataan melalui perilaku kebaikan (al-'amal alsâlib). Secara subjektif, etika Islam dalam ilmu ekonomi Islam berkaitan dengan transformasi spiritual dan moral individu dan secara objectif ianya bertapak atas dasar cinta kepada Tuhan yang termanifestasi dalam bentuk cinta kepada sesama manusia (Q.S. al-Baqarah [2]: 117). Dengan kata lain, ḩaqîqah bermaksud transformasi ajaran agama yang bersifat normatif kepada sebuah teori yang berpijak pada realitas. Norma-norma agama menjadi pengalaman manusia yang religious norms will become human experience that could be empirically observed and constructed as theory. Lihat Muhammad Fazlur-Rahman Ansari, The Qur'anic Foundations and Structure of Muslim Society (Kuala Lumpur: Islamic Book Trust, 2001), 148. Lihat juga Seyyed Hossein Nasr, Islamic Studies: Essays on Law and Security, the Sciences, and Philosophy and Sufism (Beirut: Librairie Du Liban, 1967), 109.
} 
dalam al-Qur'ân dan Sunnah. Doktrin tersebut berisi tujuan yang ingin dicapai dan juga spirit atau idealisme Islam dalam ekonomi, baik yang berhubungan dengan perilaku manusia (aspek ekonomi mikro) dan juga berkaitan dengan struktur ekonomi dan sosial masyarakat dalam konteks yang lebih besar (aspek makro ekonomi). Dimensi kedua adalah realitas praktis ekonomi baik dalam bentuk perilaku individu (aspek ekonomi mikro) atau keseluruhan struktur ekonomi (aspek makro ekonomi).

Metodologi ekonomi Islam berhubungan dengan kedua dimensi tersebut, yaitu doktrin ekonomi Islam (dimensi normatif) dan realitas ekonomi (dimensi positif), tidak secara terpisah. Sebaliknya, metodologi ekonomi Islam berusaha untuk melakukan interaksi dan integrasi kedua aspek tersebut. Teori ekonomi Islam menghubungkan doktrin (yang bersifat a priori) dan realitas (a posteriorn). Dalam hal ini, teori ekonomi Islam mempunyai dua fitur, yaitu aspek normatif (karena ia dibangun dari prinsip dan ajaran Islam tentang ekonomi) dan aspek positif (karena ia dibangun dengan memperhatikan sisi praksis aplikatif dalam dunia nyata).

Proses teoretisasi ekonomi Islam akan bermula dari dimensi doktrin untuk menentukan tujuan normatif, prinsip, dan nilai dasar ekonomi Islam. Ilmuwan ekonomi Islam berdasarkan kerangka normatif dan idealisme tersebut akan membangun asumsi dan hipotesis perilaku manusia dan fenomena ekonomi. Selanjutnya, proses teoretisasi bergerak ke dimensi realitas untuk melihat praktik dan realitas ekonomi. Pada dimensi ini, ilmuwan akan menyelidiki berbagai fakta dan data terkait dengan realitas fenomena. Selanjutnya, ilmuwan perlu melakukan analisa fakta empiris tersebut dengan kerangka normatif yang sudah ditetapkan sebelumnya. Perbedaan (gap) di antara temuan empiris dan kerangka normatif akan menjadi catatan untuk rekomendasi dan feedback agar keduanya bisa disatukan. Proses transformasi dan integrasi ini akan terus belanjut dalam proses teoretisasi ekonomi Islam seperti terlihat dalam gambar berikut ini.

Gambar 1.

Teoretisasi Ekonomi Islam

\begin{tabular}{|l|l|l|}
\hline \multicolumn{1}{|c|}{ Dimensi Doktrinal } & & Dimensi Realitas \\
\hline $\begin{array}{l}\text { Menentukan tujuan } \\
\text { normatif dan } \\
\text { menafsirkan idealisme } \\
\text { ekonomi Islam }\end{array}$ & Teori & $\begin{array}{l}\text { Melihat praktik dan } \\
\text { realitas ekonomi }\end{array}$ \\
\hline Menerjemahkan & & Menyediakan \\
\hline
\end{tabular}




\begin{tabular}{|l|l|}
\hline kerangka normatif- & informasi aktual \\
idealistik dalam & dalam bentuk \\
sebuah set asumsi dan & fakta/data realitas \\
hipotesis perilaku & ekonomi \\
manusia atau & Menganalisa fakta \\
fenomena ekonomi & empiris dan \\
Evaluasi berterusan & mengidentifikasi gap \\
dalam proses & antara aspek normatif \\
teoretisasi ekonomi & dan positif. \\
Islam & Memberikan feedback \\
& untuk mengurangi gap \\
& tersebut sebagai \\
& upaya teoretisasi \\
selanjutnya \\
\hline
\end{tabular}

Sebagai sebuah ilmu, ekonomi Islam pada hakikatnya adalah cara untuk merealisasikan tujuan atau prinsip-prinsip yang disampaikan oleh doktrin ekonomi Islam dalam dunia nyata. Sebagai sebuah ilmu, ekonomi Islam juga merupakan alat untuk menganalisa fakta/realitas dalam kerangka doktrin ekonomi Islam. ${ }^{45}$

Pada domain doktrin, ekonomi Islam berusaha untuk menentukan tujuan dan menafsirkan idealisme Islam dalam bidang ekonomi. Dari sana, ilmuwan mencoba mengembangkan kerangka asumsi perilaku ekonomi manusia untuk menjadi dasar teoretisasi ekonomi Islam. Dalam dimensi praksis, metodologi ekonomi Islam akan mengevaluasi fakta atau kondisi realitas ekonomi. Evaluasi yang dilakukan dalam dua sisi, doktrin dan realitas. Hasil dari evaluasi tersebut menjadi masukan kepada perbaikan dan penyempurnaan teori ekonomi Islam.

Di sini, kedua domain doktrin dan realitas dilihat dari perspektif integratif di mana keduanya muncul dan berkembang secara simultan dalam ekonomi Islam. Doktrin dan realitas, fakta dan nilai, akan dihubungkan dan diintegrasikan dalam teori ekonomi Islam. Interaksi ini yang bertujuan untuk mencapai kesatuan bukan saja penting, tetapi juga berlaku secara alami dalam praktik ekonomi Islam. Ini karena dua hal, yaitu: pertama, doktrin ekonomi pada hakikatnya adalah idealisasi realitas (yaitu ditetapkan untuk menginspirasi manusia bagaimana realitas-praktis seharusnya terjadi). Berdasarkan doktrin tersebut, kita bisa menderivasi berbagai postulat, asumsi dan hipotesa ekonomi; dan

\footnotetext{
${ }^{45}$ Mahmoud Abu-Saud, “Toward Islamic Economics' dalam Toward Islamization of Discipline (Herndon: IIIT, 1995), 265.
} 
kedua, fakta ataupun realitas di sisi lain pada hakikatnya adalah manifestasi idealisme pada tataran nyata (realitas).

Perkembangan teori ekonomi Islam bergantung kepada evaluasi empiris dari berbagai fakta yang terjadi dalam kerangka doktrin dan idealisme Islam. Perbedaan antara doktrin dan fakta, normatif dan positif, atau antara 'apa yang terjadi' dengan 'apa yang seharusnya' dapat diminimalisir melalui usaha penyatuan yang berterusan antara doktrin ekonomi Islam dan perilaku manusia ekonomi Islam (bomo islamicus).

Namun demikian, patut dicatat bahwa kalau doktrin bersifat tetap dan tidak berubah, asumsi dan teori yang dikembangkan tidak tetap dan bisa berubah dalam proses interaksi antara doktrin dan realitas yang terjadi. M.A. Mannan mengatakan bahwa "ketika teori ekonomi Islam diformulasikan berdasarkan konteks tertentu, ia dapat diubah, dimodifikasi ataupun dinegasi dengan teori alternatif yang lebih superior", apa yang tidak dapat diubah adalah doktrin dasar dan prinsip umum yang ditetapkan dalam al-Qur'ân dan Sunnah". ${ }^{46}$ Dalam hal ini, teori-teori tersebut tidaklah dianggap sebagai kebenaran yang absolut dan tidak berubah. Sebaliknya, teori tersebut mesti bisa merespons goncangan eksternal dinamika perubahan sosial. Dalam hal ini, teori tersebut mesti bisa difalsifikasi dalam realitas praktis dan diformulasikan sesuai dengan kebutuhan masyarakat kontemporer. ${ }^{47}$

Karena itu, dalam melahirkan teori ekonomi Islam, realitas masyarakat menjadi pertimbangan, karena jika tidak usaha ini akan siasia karena teori tersebut tidak mencerminkan dunia nyata atau tidak menggambarkan realitas yang sesungguhnya. Mannan menyebut ini sebagai internal dynamism of Islamic principles (dinamika internal prinsipprinsip Islam) yang memperhatikan dinamika realitas sehingga mempunyai implikasi mendalam terhadap perkembangan ilmu ekonomi Islam. ${ }^{48}$

\footnotetext{
${ }^{46}$ Mannan, The Making of Islamic Economic Society, 3.

${ }^{47}$ Naqvi, Islam: Economics and Society, xx.

48 M.A. Mannan berpendapat bahwa "fakta harus diuji berdasarkan nilai-nilai Islam. Kaitan antara fakta dan nilai tidak dapat dinafikan karena teori ekonomi yang dilahirkan bisa saja sesuai dengan nilai-nilai yang dianut sehingga dapat menguatkan institusi sosial ekonomi dan kebijakan yang ada. Namun demikian, teori bisa saja bertentangan dengan nilai-nilai yang dianut sehingga menginisiasi proses perubahan struktural institusi sosial ekonomi yang sudah ada." Lihat Mannan, The Making of Islamic Economic Society, 3.
} 
Tripp menggambarkan keterkaitan fakta, asumsi, teori ekonomi dan doktrin Islam dengan mengatakan bahwa "apa saja klaim ilmiah harus mempunyai akar ideologi karena ia didasari oleh doktrin fundamental mengenai hakikat manusia dan bagaimana dunia seharusnya beroperasi." ${ }^{49}$ Dengan kata lain, interkoneksi dan integrasi ini akan membawa kita mencapai kesatuan antara doktrin dan realitas.

Namun demikian, patut dicatat bahwa perbedaan antara keduanya akan selalu ada. Ini karena di antara doktrin dan realitas ada manusia yang memiliki kapasitas memanifestasikan doktrin ke dalam realitas atau tidak memanifestasikannya sama sekali. Doktrin dan teori ekonomi Islam hanya bisa terjadi jika manusia dengan sadar memilih untuk menerapkannya dalam realitas. Realitas adalah manifestasi kesadaran manusia terhadap sebuah doktrin atau prinsip ideal yang dipercayainya. Perilakunya bukanlah terjadi begitu saja, tetapi didorong oleh kesadaran, kepercayaan dan tujuan tertentu. Manusia (dalam hal ini disebut sebagai homo Islamicus) adalah aktor yang menjembantani dan menghubungkan antara doktrin dan realitas. Komitmen dan kesadaran manusia akan mengaplikasikan doktrin atau idealisme Islam ke alam realitas dangat menentukan dalam melahirkan teori ekonomi Islam.

Interaksi dan integrasi antara doktrin dan realitas bergantung kepada dua perkara, yaitu: pertama, kesadaran manusia Islam (bomo Islamicus), secara individu dan masyarakat, sebagai agen ekonomi memanifestasikan doktrin Islam ke alam realitas; atau kedua kemampuan doktrin tersebut untuk diaplikasikan dalam kehidupan nyata.

Jurang di antara keduanya akan menjadi objek kajian ekonomi Islam dan tantangan metodologi ekonomi Islam yang akan mengajukan rekomendasi bagaimana keduanya dapat didekatkan dan jurang tersebut dapat diminimalkan dan ini akan menjadi basis kepada perkembangan teori ekonomi Islam.

Dalam ekonomi Islam, masyarakat adalah laboratorium penelitian untuk meneliti fakta dan data berkaitan perilaku ekonmi. Dengan doktrin yang mencerahkan, perilaku manusia (what it is) diarahkan juga ke arah yang 'benar' menurut nilai dan prinsip Islam (what it should be). Masyarakat yang memiliki perilaku yang benar, akan memberikan data

${ }^{49}$ Charles Tripp, Islam and the Moral Economy: The Challenge of Capitalism (Cambridge, UK: Cambridge University Press, 2006), 112. 
yang benar, dan sebaliknya. Ini adalah bagian dari transformasi doktrin dan nilai dalam kehidupan dan perilaku ekonomi manusia. ${ }^{50}$

Interaksi antara doktrin dan realitas, nilai dan fakta, normatif dan positif, berlangsung secara dinamis dan multi arah dalam ekonomi Islam. Transformasi ke bawah dari doktrin menuju realitas dengan memberikan inspirasi, membimbing, dan mengoreksi realitas. Demikian juga sebaliknya, transformasi bergerak ke atas di mana realitas melakukan adopsi dan penyesuaian dengan prinsip dan nilai Islam dalam kehidupan manusia. ${ }^{51}$

Interaksi doktrin dan realitas dalam ekonomi Islam bersifat dinamis dan transformatif. Realitas praktis adalah manifestasi doktrin, dan doktrin harus berakar dalam realitas. Ekonomi Islam sebagai sebuah ilmu mengambil perhatian interaksi dan integrasi doktrin dan realitas.

Tugas dan cakupan kajian ekonomi Islam pada level teoretis adalah untuk membangun sebuah skema normatif perilaku manusia yang terinspirasi dari doktrin Islam dan juga aplikatif (dapat diterapkan di alam realitas). Pada tataran praksis, ekonomi Islam juga dituntut untuk mengembangkan teori yang bisa menjelaskan realitas dengan lebih komprehensif dan juga bisa diaplikasikan. Dengan interaksi doktrin dan realitas, teori ekonomi Islam berusaha memahami dan menjelaskan realitas yang ada dan menyediakan arah yang seharusnya. Dengan kata lain, teori ekonomi Islam tidak memlulu bersifat deskriptif, tetapi juga transformatif dan mencerahkan.

\section{Penutup}

Teori ekonomi Islam dikonstruk berdasarkan prinsip epistemologi Islam yang mengakui al-Qur'ân dan Hadîth sebagai sumber ilmu pengetahuan, di samping fakta empiris dan akumulasi pengalaman manusia (facts) dan penalaran akal (intellectual reasoning). Sebagai sebuah ilmu, ekonomi Islam berusaha melakukan interaksi, integrasi, dan interkoneksi antara doktrin dan realitas ekonomi. Doktrin merupakan prinsip-prinsip yang digali dari al-Qur'ân dan Hadîth. Doktrin tidak dimaksudkan untuk dirinya sendiri. Sebaliknya, doktrin harus

\footnotetext{
${ }^{50}$ M. Raihan Sharif, "Some Thoughts on the Methodology of Islamic Economics", dalam Abdul Rashid Moten dan Bajulaiye-Shasi (eds.), Nature and Methodology of Islamic Economics (Kano, Nigeria: Bayero University, 1990), 132.

51 Mohamed El-Tahir El-Mesawi, "The Methodology of al-Tafsîr al-Mawdûti: A Comparative Analysis", Intellectual Discourse, Vol. 13, No. 1 (2005), 16.
} 
dimanifestasikan dalam dunia realitas. Karena itu, realitas merupakan manifestasi dari doktrin. Realitas yang menyimpang dari doktrin atau doktrin yang bertentangan dengan realitas akan menjadi bahan evaluasi dan penilaian lebih lanjut dalam teoretisasi ekonomi Islam.

Metodologi ekonomi Islam dalam proses teoretisasi berupaya menyatukan ketiga sumber ilmu tersebut dan antara doktrin dan realitas. Prinsip yang dipegang adalah tidak ada dikotomi antara 'fakta' (facts) dan 'nilai' (values), realita objektif (objective reality) dan perasaanemosi subjektif (subjective emotions) atau nilai-nilai normatif (normative values) seperti dalam epistemologi ilmu-ilmu modern. Dalam hal ini, metodologi ekonomi Islam berusaha melahirkan teori ekonomi Islam dari berbagai sumber ilmu yang diakui dalam epistemologi Islam, seperti wahyu, logika akal, dan fakta atau pengalaman nyata. Kebenaran yang ingin dicapai bukan kebenaran dari segi doktrin saja (doctrinal truth), tetapi juga kebenaran yang rasional (logical truth) dan kebenaran empiris (empirical trutb). Ketiga dimensi kebenaran tersebut harus menyatu dalam teori ekonomi Islam. Pergulatan antara doktrin dan realitas dalam teori ekonomi Islam akan berlangsung secara terus menerus dan penuh dinamika membentuk bangunan ilmu (body of knowledge) ekonomi Islam.

\section{Daftar Rujukan}

Abdul-Rauf, Muhammad. Ummah and the Muslim Nation. Kuala Lumpur: Dewan Bahasa dan Pustaka, 1991.

Abu-Saud, Mahmoud. 'Toward Islamic Economics' dalam Toward Islamization of Discipline. Herndon: IIIT, 1995.

al-Attas, Syed Muhammad Naquib. "Preliminary Thoughts on the

Nature of Knowledge and the Definition and Aims of Education", dalam Syed Muhammad Naquib Al-Attas (ed.), Aims and Objectives of Islamic Education. Jeddah: King Abdul Aziz University, 1979.

al-Sadr, Muhammad Baqir. "General Edifice of the Islamic

Economy" dalam Jomo K.S (ed.), Islamic Economics: Contemporary Ulama Perspectives. Kuala Lumpur: Iqra', 1991.

-----. Iqtisaduna: Our Economics. Tehran, Iran: World Organization for Islamic Services, 1983.

Ansari, Muhammad Fazlur-Rahman. The Qur'anic Foundations and Structure of Muslim Society. Kuala Lumpur: Islamic Book Trust, 2001. 
Askari, Hasan. "Islamic Definition of the Economics" dalam Society and State in Islam: An Introduction. Lahore, Pakistan: Progressive Books, 1979.

Biraima, Mohammad E. "A Quranic Model for a Universal Economic Theory", JKAU: Islamic Economics, Vol. 3, 1991.

Chapra, M. Umer. The Future of Economics: An Islamic Perspective. UK: The Islamic Foundation, 2000.

El-Mesawi, Mohamed El-Tahir. "The Methodology of al-Tafsîr alMawdû́ $i$ : A Comparative Analysis", Intellectual Discourse, Vol. 13, No. 1, 2005.

Galbraith, John Kenneth. "Economics as A System of Belief', dalam Andrea D. Williams (ed.), A Contemporary Guide to Economics, Peace, and Laughter. USA: Houghton Muffin Company, 1971.

Haneef, Mohamed Aslam. "Islam: the Islamic Worldview and Islamic Economics", IIUM Journal of Economics and Management, Vol. 5, No. $1,1997$.

Heilbroner, Robert. "Economics As Ideology", dalam Warren J. Samuels (ed.), Economics As Discourse: An Analysis of the Language of Economics. USA: Kluwer Academic Publishers, 1990.

Husaini, S. Waqar Ahmed. "Science, Technology and Environment in Islamic Culture: Basic Principles and Implications" dalam Klaus Gottstein (ed.), Islamic Cultural Identiy and Scientific-technological Development. Germany: Nomos Verlagsgesellschaft, 1986.

Kamali, Muhammad Hashim. "Islam, Rationality and Science" Islam and Science, Vol. 1, No. 1, 2003.

Kamali, Muhammad Hashim. "Reading the Signs: A Quranic Perspective on Thinking", Islam and Science, Vol. 4, No. 2, 2006.

Khan, Muhammad Akram. "Methodology of Islamic Economics", Journal of Islamic Economics, Vol. 1, No. 1, 1987.

Mannan, M. A. Islamic Economics: Theory and Practice. Cambridge: Hodder and Stoughton, 1986.

Naqvi, S. N. H. Ethics and Economics: An Islamic Synthesis. United Kingdom: The Islamic Foundation, 1981.

----. Islam: Economics and Society. London: Kegan Paul International, 1994.

Nasr, Seyyed Hossein. "The Islamic Worldview and Modern Science, MAAS Journal of Islamic Science, Vol. 10, No. 2, 1994.

----. Islamic Studies: Essays on Law and Security, the Sciences, and Pbilosophy and Sufism. Beirut: Librairie Du Liban, 1967. 
Nienhaus, Volker. "Islamic Economics: Dogma or Science" dalam Kay Hafez (ed.), The Islamic World and the West. Leiden: EJ Brill, 2000.

-----. "Restaments of Normative Economics: Western Approach and Islamic Perspectives" dalam Masudul Alam Choudhury (ed.), Policy-Theoretic Foundations of Ethico-Economics. Cape Bretton: The Centre of Humanomics, University College of Cape Bretton, 1988.

Rahman, Fazlur. "Islam and the Problem of Economic Justice" Journal of Islamic Economics, Vol. 3, No. 2, 1995.

Safi, Louay. The Foundation of Knowledge: a Comparative Study in Islamic and Western Methods of Inquiry. Kuala Lumpur: International Islamic University and International Institute of Islamic Thought, 1996.

Sardar, Ziauddin. Islamic Futures: The Shape of Ideas to Come (Islamic Futures and Policy Studies). New York: Mansell, 1986.

-----. How Do You Know? Reading Ziauddin Sardar on Islam, Science, and Cultural Relations. London: Pluto Press, 2006.

Sharif, M. Raihan. "Some Thoughts on the Methodology of Islamic Economics", dalam Abdul Rashid Moten dan Bajulaiye-Shasi (eds.), Nature and Methodology of Islamic Economics. Kano, Nigeria: Bayero University, 1990.

----. Guidelines to Islamic Economics: Nature, Concepts, and Principles. Bangladesh: Bangladesh Institute of Islamic Thought, 1996.

Siddiqi, Muhammad Nejatullah. The Economic Enterprise in Islam. Lahore, Pakistan: Islamic Publications, Cet Ke-2, 1979.

Spengler, Joseph J. Origins of Economic Thought and Justice: Political and Social Economy. Carbondale: Southern Illinois University Press, Carbondale, 1980.

Tripp, Charles. Islam and the Moral Economy: The Challenge of Capitalism. Cambridge, UK: Cambridge University Press, 2006.

Wisman, Jon D. "Economic Science's Bondage to the Material Progress Vision", Humanomics, Vol. 8 No. 2, 1992. 